\title{
The potential effects of anabolic- androgenic steroids and growth hormone as commonly used sport supplements on the kidney: a systematic review
}

\author{
Dorna Davani-Davari ${ }^{1}$, Iman Karimzadeh ${ }^{1 *}$ (1) and Hossein Khalili'
}

\begin{abstract}
Background: Anabolic-androgenic steroids and growth hormone are among the most commonly used supplements by sportsmen and sportswomen. The aim of this systematic review is to collect and report available data about renal safety of anabolic-androgenic steroids and growth hormone (GH).

Methods: The search strategy was in accordance with the PRISMA guideline. Seven databases such as Scopus, Medline, Embase, and ISI Web of Knowledge were searched using keywords, such as "growth hormone", "anabolicandrogenic steroids", and "kidney injury". Articles published from 1950 to December 2017 were considered. Randomized clinical trials, prospective or retrospective human studies, case series as well as case reports, and experimental (in vivo) studies were included. Twenty one clinical and experimental articles were selected (12 for anabolic-androgenic steroids and 9 for $\mathrm{GH}$ ).

Results: Anabolic-androgenic steroids can affect the kidney in different aspects. They can induce or aggravate acute kidney injury, chronic kidney disease, and glomerular toxicity. These adverse effects are mediated through pathways such as stimulating renin-angiotensin-aldosterone system, enhancing the production of endothelin, producing reactive oxygen species, over-expression of pro-fibrotic and pro-apoptotic mediators (e.g., TGF- $\beta 1$ ), as well as inflammatory cytokines (e.g., TNF-a, IL-1b, and IL-6). Although GH may affect the kidney in different aspects, such as size, glomerular filtration rate, and tubule functions, either directly or indirectly, there is no conclusive clinical evidence about its detrimental effects on the kidney in athletes and body builders.

Conclusion: Evidence regarding effects of anabolic-androgenic steroids exists; However, GH's exact effect on the kidney at doses used by athletes and body builders has not yet been clarified. Cohort clinical studies with longterm follow-up are warranted in this regard.
\end{abstract}

Keywords: Sport supplements, Growth hormone, Anabolic-androgenic steroids, Kidney, Adverse effects

\section{Background}

For the first time in the literature in 1991, at an international Consensus Conference related to the International Olympic Committee, a statement began to become bold: "Diet significantly influences exercise performance" [1]. However, it has been reported that the

\footnotetext{
* Correspondence: karimzadehiman@yahoo.com

${ }^{1}$ Department of Clinical Pharmacy, Faculty of Pharmacy, Shiraz University of Medical Sciences, Karafarin street, P O Box: 7146864685, Shiraz, Iran Full list of author information is available at the end of the article
}

ancient Egyptians, Greeks, and Romans used performance enhancing drugs for the first time in history [2].

In 2016, a total amount of $\$ 5.67$ billion was spent for dietary supplements and related nutrition products in the United States (US) [3]. According to the Lieberman et al. study on 1248 US college students, supplements including multivitamins/multiminerals [42\%], vitamin C [18\%], protein/amino acids [17\%] and calcium [13\%] were used to improve muscle strength in $20 \%$ of supplement consumers. Performance enhancement (19\%) and elevation of endurance level (7\%) were other intensions

(c) The Author(s). 2019 Open Access This article is distributed under the terms of the Creative Commons Attribution 4.0 International License (http://creativecommons.org/licenses/by/4.0/), which permits unrestricted use, distribution, and 
of using supplements in this study [4]. In 2014, statistics indicated that protein supplements (41.7\%), energy drinks and shots (28.6\%), creatine (14.0\%), amino acids (12.1\%), multivitamins with caffeine (5.7\%), beta-hydroxy-beta-methylbutyrate $(0.2 \%)$, dehydroepiandrosterone $(0.1 \%)$, and an unspecified mix of "testosterone boosters" (1.6\%) were commonly used among 21,000 US college athletes [5]. Anabolic-androgenic steroids are frequently used by bodybuilders and weightlifters as dietary supplements [6].

Although supplements are commonly utilized by athletes for improving lean body mass and muscle strength, it may be plausible that they can be harmful for human health. Since kidney is a crucial site for both the metabolism and excretion of exogenous substances, it may be adversely affected by sport supplements. In this regards, for example, Daher et al reported that a series of 16 subjects with kidney complications, including acute kidney injury (AKI) had been admitted into two referral hospitals in Brazil secondary to excessive and prolonged use of veterinary intramuscular injection supplements of vitamin A (20,000,000 IU), D (35,000,000 IU) and E $(6,000 \mathrm{IU})$ [7]. In a case series from 20 Iranian male body-builders, toxic hepatitis secondary to chronic ingestion of dietary supplements including creatine and testosterone were documented [8]. However, to the best of our knowledge, there is no published article or official report about possible adverse effects of dietary supplements on the kidney in Iranian athletes especially their well-known Olympic weightlifters. Even if it has been studied, that the results may be largely negative.

The aim of this review is to collect available experimental and clinical data about renal safety of anabolic-androgenic steroids and growth hormone, as two prominent hormonal sports supplements.

\section{Methods}

This systematic review was prepared according to the PRISMA (Preferred Reporting Items for Systematic reviews and Meta-Analyses) guideline [9]. A literature search was performed in 7 relevant databases, including Scopus, Medline, Embase, ISI Web of Knowledge, Cochrane central register of controlled trials, Cochrane database systematic reviews, and Google Scholar. To confirm consistency and accuracy of results, searches were performed by two authors independently (DDD \& IK). At 3 stages, titles, abstracts, and full text of studies were evaluated. At the final stage, required data was extracted from the selected articles. The following keywords were used as search terms: "anabolic steroids", "androgenic steroids", "anabolic-androgenic steroids", "androgens", "anabolics", "growth hormone", "recombinant human growth hormone", "somatropin", "acute kidney injury", "chronic kidney disease", "renal dysfunction", "renal impairment", "renal damage", and "renal insufficiency". Randomized clinical trials, prospective or retrospective human studies, case series as well as case reports, and experimental (in vivo) studies were included in this review. The reference lists of published articles were also examined for identifying any additional relevant studies. Regarding publication date, articles published from 1950 to December 2017 were considered in this review. Non-English language articles, congress abstracts, newspaper articles, and in vitro studies were not eligible for inclusion. The studies included in the systematic review were reviewed by all the authors to ensure that they met the inclusion criteria. Any possible discrepancies were discussed by the authors. By taking into account the above inclusion and exclusion criteria, 21 published articles were considered in our review. These articles included experimental studies $(n=$ $8)$, case report or case series $(n=8)$, pilot clinical trial $(n=3)$, placebo-controlled, cross-over clinical trial $(n=$ $1)$, and randomized, cross-over clinical trial $(\mathrm{n}=1)$. Quality of clinical studies was evaluated using the Jadad score. This score for the studies concerning growth hormone $(n=5)$ ranged from -1 to +2 . Figure 1 depicts the flow diagram of our study selection process. 1327 and 3341 studies relevant to anabolic-androgenic steroids and growth hormone respectively, were excluded from this systematic review. This exclusion was mainly due to duplication in different databases.

\section{Discussion}

\section{Anabolic-androgenic steroids}

A statistics in 2007 showed that $67 \%$ of athletes in the US utilized anabolic-androgenic steroids [10]. Not only athletes, but also in the general population, especially youngsters used these agents to enhance their muscular appearance [11]. An investigation in Brazil showed that more than 25 compounds, including anabolic substances (such as Durasteron [testosterone], Stradon P [testosterone+ stradiol], Deca-durabolin [nandrolone], Uniciclo [algestone +stradiol] and Premarim [estrogens]) have been used by young bodybuilders to improve and accelerate their muscle mass gains [12]. Anabolic-androgenic steroids abuse has become particularly prevalent in regions, such as Scandinavia, the US, Brazil, and British Commonwealth countries [13]. Interestingly, a survey in 2006 revealed that only 38\% of interviewed athletes were aware of side effects related to anabolic steroids [14]. Commercial magazines relevant to body builders may downplay side effects of anabolic-androgenic steroids, including cholestatic liver injury, testicular atrophy, sexual dysfunction, and, age-related cardiovascular disease.

Historically, anabolic-androgenic steroids were utilized for the treatment of anemia instead of erythropoietin in 


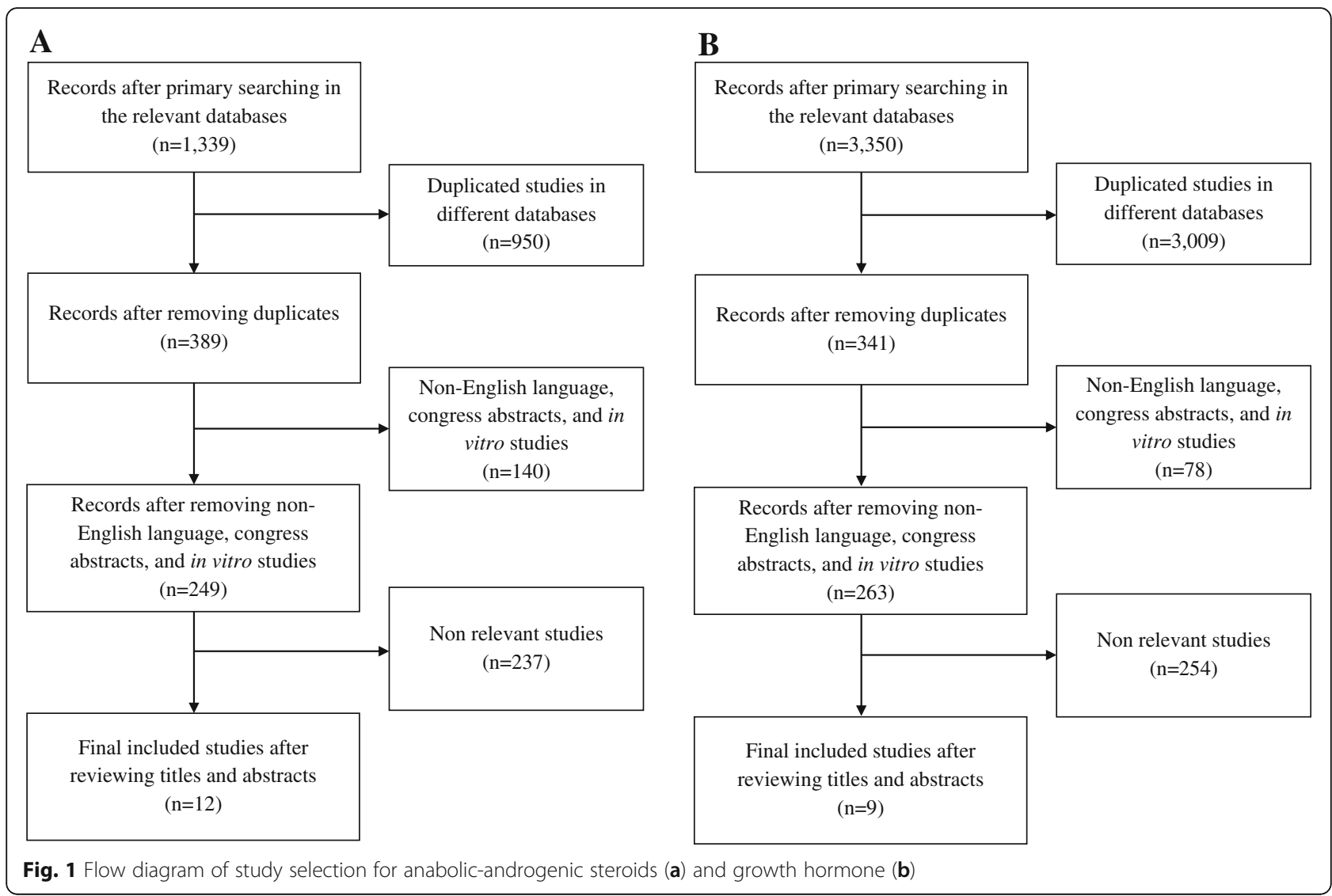

individuals with chronic kidney disease (CKD). Their doses for anemia treatment was generally lower than their doses in doping [15]. However, the use of androgens for the treatment of anemia in CKD patients has been stopped because of inconsistent erythropoietic response, many adverse effects, and the availability of recombinant erythropoietin as a more effective and safer agent [16]. Currently, anabolic-androgenic steroids are used by both elite professionals and amateur athletes to improve body image (through an increase in muscle and/or decrease in fat mass) and also exercise performance [17].

In addition to well-defined and -known adverse effects of androgens, including acne, virilization, priapism, testicular atrophy, gynecomastia, liver dysfunction, injection-site pain, peliosis, hepatitis, and hepatocellular carcinoma [18], they can also cause kidney dysfunction which is not well described. Mostly, kidney complications occur after long-term administration of anabolic-androgenic steroids. They range from a single increased serum creatinine to AKI as a complication of rhabdomyolysis or liver damage (bile acid nephropathy or cholemicnephrosis), renal histological changes, such as focal segmental glomerulosclerosis (FSGS), tubular atrophy, and interstitial fibrosis [19]. The detailed description of acute and chronic adverse effects of anabolic-androgenic steroids on renal function has been provided in the following sections.

\section{Acute kidney injury (AKI)}

In 2009, Daher et al. reported the case of a 21-year-old male athlete, admitted to the emergency department with complaints of nausea, progressive abdominal pain, dizziness, vomiting, headache, weakness, fever, and profuse sweating in the last month. Nausea and vomiting were in association with oliguria and arterial hypertension $(160 / 120 \mathrm{mmHg})$. The results of laboratory tests upon admission indicated an increase in the serum levels of calcium $(13.2 \mathrm{mEq} / \mathrm{L})$, creatinine $(3.9 \mathrm{mg} / \mathrm{dL})$, and urea $(79 \mathrm{mg} / \mathrm{dL})$. The urinary analysis indicated leukocyturia $(+++)$, hematuria $(+)$, and proteinuria (traces). The amount of protein in the 24-h urine was $259 \mathrm{mg}$. The kidney size and renal arteries were normal. The renal biopsy showed moderate interstitial inflammatory infiltrates with eosinophils, calcium deposits, tubular necrosis, and interstitial edema. History-taking revealed that the patient was receiving anabolic steroids and veterinary supplements containing vitamin A, vitamin D, and vitamin E, respectively $(20,000,000,35,000,000$, and $6000 \mathrm{IU}$, respectively). All causative agents were discontinued, and hypertension and hypercalcemia were controlled via pharmacotherapy. The patient was discharged 
with almost normal renal function after 20 days. In this study, the case of a 30-year-old man, experiencing nausea, vomiting, diarrhea, and fever in the past month before admission, was also reported. He was referred to the emergency department with the main complaint of persistent vomiting. The physical examination revealed the patient's good general condition, except for abdominal pain upon palpation. According to the laboratory tests upon admission, the serum levels of urea $(52 \mathrm{mg} /$ $\mathrm{dl})$, creatinine $(1.9 \mathrm{mg} / \mathrm{dl})$, and calcium $(11 \mathrm{mEq} / \mathrm{l})$ increased. The urinalysis showed blood $(+)$ and protein $(++)$. Also, the urinary level of calcium was $390 \mathrm{mg} / 24 \mathrm{~h}$. The kidney size was normal. The patient confirmed the use of anabolic steroids and veterinary supplements containing vitamin A, vitamin D, and vitamin E $(20,000,000$, $35,000,000$, and $6000 \mathrm{IU}$, respectively) in the past two years before admission. In addition, the patient was receiving $12 \mathrm{mg}$ of dexamethasone every two weeks. Despite intravenous hydration and administration of furosemide and prednisolone $(1 \mathrm{mg} / \mathrm{kg}$ per day), renal function did not improve. The renal biopsy revealed mild interstitial lymphmononuclear inflammatory infiltrates with eosinophils, without any remarkable tubular abnormalities. After discontinuing the use of these agents, the patient's renal function gradually recovered after one month of hospitalization [20]. The authors also briefly described 14 other cases of AKI and relevant complications (e.g., cholestasis and rhabdomyolysis) associated with anabolic steroids (e.g., metandienone, stanozolol) and vitamin supplements (e.g., vitamins D and A) in males and females aged between 21 and 63 years published in the literature between 1988 and 2009. They demonstrated that apart from potential adverse effects of anabolic steroids on the kidney, interstitial nephritis, hypercalcemia, and nephrocalcinosis secondary to vitamin D intoxication were also capable of inducing renal dysfunction in these cases. Rhabdomyolysis has been reported in the setting of AKI due to anabolic-androgenic steroids and it can independently induce or aggravate AKI caused by these agents [20]. Nephrocalcinosis secondary to exogenous vitamin $\mathrm{D}$ intoxication in a bodybuilder athlete has been described in another case report [21].

Almukhtar et al. in 2015 also reported 4 bodybuilders referred to the nephrology department of a university hospital with the chief complaint of weakness and lethargy. All patients had taken more than $400 \mathrm{mg} /$ week testosterone proprionate and/or nandrolone decanoate intramuscularly. They also had consumed supplementary proteins (containing 78-104 $\mathrm{g}$ of whey powder added to regular dietary protein including $2-3 \mathrm{~L}$ of milk to reach $278-354 \mathrm{~g}$ daily) and creatine ( $15 \mathrm{~g}$ per day). Their serum creatinine and estimated glomerular filtration rate (eGFR) were $229.84-335.92 \mu \mathrm{mol} / \mathrm{L}$ and $0.37-0.57 \mathrm{~mL} / \mathrm{s}$, respectively. Renal biopsy revealed acute tubular necrosis. By discontinuing all the above agents, serum creatinine became normal within four weeks. The authors attributed AKI in the bodybuilders to the combination effects of excess creatine and protein with steroid injections along with hypervitaminosis $\mathrm{D}$ and phosphate nephropathy [22].

Bile acid nephropathy, also known as cholemic nephrosis, can be typically associated with AKI. At least 3 case reports published between 2014 and 2016 described bile acid nephropathy secondary to cholestatic jaundice caused by anabolic steroids in bodybuilders with no underlying liver or kidney diseases. The abused anabolic steroids in the above case reports were oral or injectable stanazolol, injectable nandrolone, injectable testosterone, and oral methandrostenolone consumed for 5 to 6 weeks or oxandrolone, boldenone undecyclenate, stanazolol, and trenabol for an unidentified duration. Hyperbilirubinemia, increased serum creatinine, oliguria and tubular bile acid casts in urine specimen were observed in the cases. All AKI episodes were resolved by either only discontinuing the offending medication or along with supportive care and renal replacement therapy [19, 23, 24].

Regarding the effects of endogenous sex hormones on the urinary markers of nephrotoxicity, an experimental study in rats demonstrated that there was a significant association between testosterone and urinary excretion of leucine aminopeptidase, alkaline phosphatase, $\gamma$-glutamyl transpeptidase, cystatin $C$ and $\beta 2$-microglobulin, as biomarkers of kidney's proximal tubule [25]. The authors stated that these data should be considered in the accurate interpretation of studies about markers of nephrotoxicity in animals.

\section{Chronic kidney diseases (CKD)}

Endocrine dysfunctions, such as testosterone deficiency and hypogonadism may occur in male patients with CKD [26]. These dysfunctions are associated with a higher risk of morbidity and mortality, possibly due to anemia, mineral as well as bone disorders (osteoporosis \& osteodystrophy), and cardiovascular diseases in CKD individuals [27]. Conversely, exogenous testosterone administration can also cause renal dysfunction, renal injury progression, and proteinuria [28]. Anabolic-androgenic steroids can cause or exacerbate CKD and also kidney fibrosis or sclerosis with different mechanisms:

Renal blood pressure regulation Since androgen receptors are located in different parts of the kidney and on the other hand, various enzymes involved in testosterone synthesis pathway are produced in the kidney tissue, it is conceivable that testosterone is able to regulate renal artery blood pressure (BP) [27].

Testosterone can increase renal artery BP, probably via potentiating the renin-angiotensin-aldosterone system 
(RAAS) along with the up-regulation of endothelin. RAAS can increase BP and water retention through promoting tubular sodium and water re-absorption $[29,30]$. An experimental investigation in male rats revealed that androgens potentiate Ang II-induced renal vascular responses, partly via up-regulation of the Rho kinase signaling pathway [31]. Rho kinase signaling pathway can increase the resistance of peripheral vessels, leading to BP elevation [32]. This signaling pathway is involved in the pathogenesis of CKD [31]. Interestingly, a study in hypertensive female rats under high-sodium diet revealed that exogenous testosterone is involved in development of hypertension [33]. Furthermore, a study on orchidectomized adult male Sprague-Dawley rats demonstrated that a subcutaneous injection of testosterone for 7 days with a dose of $125 \mathrm{mg} / \mathrm{kg} /$ day or $250 \mathrm{mg} / \mathrm{kg} /$ day can increase water re-absorption. A resulting effect can be rise in BP by the expression of aquaporin types $1 \& 7$ in the proximal convoluted tubule and $2,4 \& 6$ in the collecting ducts [34]. Paradoxically, low levels of endogenous testosterone can also lead to high BP [35]. In this regards, men with hypertension had lower levels of testosterone compared with normotensive ones of the same age [36]. In addition, restoration of testosterone levels to normal range in hypogonadal men decreased BP [37]. The exact explanation for these paradoxical effects of androgens on BP was unknown.

Endothelin Testosterone can enhance the production of endothelin directly or indirectly (via RAAS) [30, 38]. Endothelin can result in vasoconstriction (both afferent and efferent arterioles) and promotion of mitogenic activity through its type A receptor. This receptor is exclusively expressed by vascular smooth muscle cells in the kidney. The role of endothelin in pathophysiological conditions, such as diabetic nephropathy, and immune nephritis has been also implicated [39]. Therefore, testosterone may be involved in both kidney fibrosis and ischemia-reperfusion injury via both local and systemic effects of endothelin [27].

Oxidative stress Anabolic-androgenic steroids may play a role in the development of CKD via producing reactive oxygen species and promoting oxidative stress [40]. In this regards, orchidectomy has been demonstrated to attenuate oxidative stress-mediated kidney fibrosis and proteinuria after ureteral obstruction in male rats [41]. Testosterone can cause oxidative stress directly, as well as indirectly via activation of the RAAS and endothelin (through up-regulating NADPH oxidase) [27].

Apoptosis \& Inflammatory cytokines Apoptosis, another contributory factor in kidney fibrosis development, can be induced by various inflammatory cytokines.
Androgens play a crucial role in apoptosis. For example, androgens can induce apoptosis of renal tubular cells through triggering a caspase-dependent apoptotic pathway [42]. In addition, testosterone may be involved in the production of pro-inflammatory cytokines such as, tumor necrosis factor a (TNF- $\alpha$ ), interleukin-1b (IL-1b), and interleukin- 6 (IL-6). The production of such cytokines can lead to renal inflammation and CKD progression [43-45]. Reciprocally, inflammatory cytokines, such as TNF- $\alpha$ and IL- 6 can enhance the activity of androgen receptors [46, 47]. Accordingly, Metcalfe et al. demonstrated that TNF- $\alpha$ production, pro-apoptotic, as well as pro-fibrotic signaling and consequently, level of tubule-interstitial fibrosis and kidney dysfunction were increased in normal male rats. This increase can lead to endogenous production of testosterone and oophorectomized female rats treated by exogenous testosterone [28]. Moreover, exogenous administration of testosterone has shown to induce podocyte apoptosis and glomerulosclerosis in female estrogen receptor-knockout mice [48].

\section{Progression of CKD}

A number of investigations have shown a relation between the male gender and multiple kidney disorders, such as IgA nephropathy, polycystic kidney disease, and membranous nephropathy. Therefore, androgens can be involved in the progression of CKD [49-51]. Accordingly, in diabetic nephropathy, male gender is a risk factor for proteinuria progression [52]. In contrast, some evidence suggested that an imbalance in sex hormones' ratio (rather than androgen excess alone) may cause or aggravate kidney dysfunction. For example, Maric et al. demonstrated that lower levels of endogenous testosterone and higher levels of blood estradiol were associated with the development of diabetic nephropathy in men [53]. Administration of exogenous testosterone and aromatase inhibitors can restore dihydrotestosterone and estradiol levels to their physiological range. Consequently, they can even act as renal protective agents in the progression of diabetic nephropathy via reducing inflammatory process and fibrosis $[54,55]$.

$\mathrm{Xu}$ et al. demonstrated a dose-dependent relation between administration of exogenous dihydrotestosterone and albuminuria, glomerulosclerosis, and tubule-interstitial fibrosis progression in castrated male diabetic rats. Administration of $0.75 \mathrm{mg} /$ day dihydrotestosterone (low dose) had nephroprotective effects; whereas, administration of $2.0 \mathrm{mg} /$ day dihydrotestosterone (high dose) accelerated renal injury process. Additionally, estradiol could affect the dose-dependent action of dihydrotestosterone on the kidneys [56]. 


\section{Glomerular toxicity}

Herlitz et al. in 2010 described variable degrees of renal insufficiency, proteinuria, and nephrotic syndrome in 10 bodybuilders with the mean age of 37 years abusing anabolic steroids. At least one anabolic-androgenic steroid, usually combined with dietary supplements (e.g., monohydrate, creatine, and a high-protein diet). They manifested along with proteinuria and renal insufficiency (mean creatinine level, $3.0 \mathrm{mg} / \mathrm{dl}$ ). Nephrotic syndrome was detected in three out of $10(30 \%)$ patients. According to the renal biopsy, FSGS and $\geq 40 \%$ tubular atrophy and interstitial fibrosis were found in nine and three patients, respectively. Among all seven patients with long-term follow-ups, discontinuation of anabolic steroids, along with the use of RAAS blockers and/or corticosteroids, has led to the improvement or stabilization of serum creatinine, weight loss, and proteinuria reduction. The authors hypothesized that secondary FSGS in anabolic-androgenic steroid abusers may be related to different pathways: 1) an increase in lean body mass which may result in glomerular hyperfiltration; 2) overexpression of a potent profibrotic and proapoptotic cytokine (TGF- $\beta 1)$; 3) induction of oxidative stress; and 4) upregulation of RAAS components. The last three mechanisms can be attributed to the potential toxic effects of anabolic-androgenic steroids on glomeruli. Besides these mechanisms, other factors including high-protein diet (by increasing the renal blood flow and GFR) and elevated blood pressure (via hypertensive arterionephrosclerosis) may have additive/synergistic adverse effects on glomeruli [57].

One year later, Harrington et al. reported another case of secondary FSGS caused by anabolic steroid abuse in a 38-year-old man. History taking revealed regular use of anabolic steroids, both orally and intramuscularly since the age of 18. Para clinical evaluation demonstrated high serum creatinine $(1797 \mu \mathrm{mol} / \mathrm{l})$, increased serum urea concentration $(55.2 \mathrm{mmol} / \mathrm{l})$, low hemoglobin level $(6.0$ $\mathrm{g} / \mathrm{l}$ ), intrinsic renal parenchymal damage, and FSGS. The patient required renal replacement therapy due to his end-stage renal disease (ESRD). Hemodialysis and after that, continuous ambulatory peritoneal dialysis were initiated for him [58]. It is noteworthy that these two reports are just case descriptions and obviously, not epidemiological studies. A summary of published experimental and clinical studies regarding renal safety of anabolic-androgenic steroids is shown in Table 1 in the order of study type (first experimental and after that clinical) and publication year.

In brief, regular, long-term use of anabolic-androgenic steroids can induce various renal disorders directly or indirectly through different mechanisms [19]. Some mild renal abnormalities, such as increase in serum creatinine, blood urine nitrogen, or uric acid, without sclerotic/ fibrotic morphological alteration or decrease in cystatin C clearance, can be recovered after discontinuing anabolic-androgenic steroids [59]. However, their consumption by some individuals may be associated with poor kidney prognosis, resulting in ESRD. As a result, well-designed clinical studies are warranted to examine the exact pathological effects and roles of different doses of endogenous or exogenous androgens on the progression of kidney dysfunction in patients with CKD.

\section{Growth hormone}

Growth hormone $(\mathrm{GH})$ treatment has been initiated since 1960s in children with impaired growth [60]. At first, this hormone was extracted from donor pituitaries. Almost in 1980s, recombinant forms of this hormone was manufactured, and its utilization was extended [61]. This agent has been currently approved by the FDA for use in GH failure or short stature, due to Turner, Prader-Willi, or Noonan syndromes, as well as, idiopathic short stature, HIV-associated cachexia, and short bowel syndrome in adults [62].

\section{Growth hormone sources in the body, its biological effects, and general safety}

$\mathrm{GH}$ is a polypeptide hormone [63]. $\mathrm{GH}$ genes are expressed in pituitary somatotropic cells, placenta, and to a lesser extent in lymphocytes [64]. GH expression in lymphocytes is merely adequate for local paracrine/autocrine regulations, and all physiological actions of this hormone are mediated by pituitary and placental GH [65]. The most important sites of GH metabolic clearance are the kidneys and liver [65].

GH plays a crucial role in some biological activities, including nitrogen retention, amino acid transportation into muscle, promotion of somatic growth, growth plate elongation, generation of insulin-like growth factor I (IGF-I) and insulin-like growth factor binding protein 3 (IGFBP), lipolysis, sodium or phosphorus retention, producing insulin antagonistic effects, cell hyperplasia, and lactogenesis [65]. GH can also convert T4 to T3 and active cortisone to its inactive form [66].

Due to the beneficial effects of GH on lean body mass, and performance, as well as not being detected within the body, GH abuse is very common among athletes [67, 68]. Although a systematic review in 2008 claimed that GH can elevate lean body mass [69], at least one randomized, placebo-controlled, blinded study demonstrated that this increase in lean body mass is primarily the result of the extracellular water volume expansion [70]. However, some evidence suggested that an increase in GH level may enhance physical performance, increase tolerance for hard training, and shorten recovery time after exercise [71]. 
Table 1 Summary of experimental and clinical studies about the renal safety of anabolic-androgenic steroids $(n=12)$

\begin{tabular}{ll}
\hline Dose \& Duration & Subjects \\
\hline $\begin{array}{l}50 \mathrm{mg} / \text { day dihydrotestosterone } \\
\text { intraperitoneally for } 10 \text { days }\end{array}$ & Rats \\
& \\
$500 \mu \mathrm{g} / \mathrm{kg} /$ day testosterone propionate & $\begin{array}{l}\text { Castrated male and } \\
\text { intramuscularly for } 2 \text { weeks } \\
\text { rats with obstructive renal } \\
\text { injury }\end{array}$ \\
$\begin{array}{l}0.75 \text { or } 2.0 \mathrm{mg} / \text { day dihydrotestosterone as } \\
\text { subcutaneous implants for } 14 \text { weeks }\end{array}$ & $\begin{array}{l}\text { Castrated diabetic male rats } \\
\end{array}$
\end{tabular}
subcutaneous implants for 14 weeks

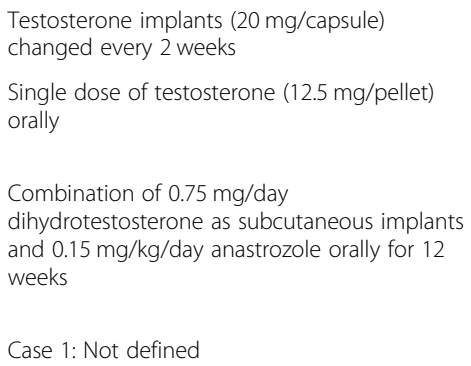
$\begin{array}{ll}\text { Oxandrolone, boldenone undecyclenate, } & \text { 28-year-old male } \\ \text { stanozolol, and trenabol (with not-defined daily } & \text { bodybuilder }\end{array}$
Hypertensive rats on a high sodium diet

\section{Female estrogen receptor} knockout mice

Diabetic male rats

Case 1: 21-year-old male athlete

Case 2: 30-year-old male bricklayer

Case series: Males \& Females aged between 21 and 63 years

10 body builders aged between 28 and 49 years

38-year-old man

41-year-old male bodybuilder

Case 1: 30-year-old male amateur bodybuilder Case 2: 43-year-old male amateur bodybuilder

\begin{tabular}{|c|c|}
\hline $\begin{array}{l}\text { Type of } \\
\text { study }\end{array}$ & Main results \\
\hline Experimental & $\begin{array}{l}\text { - Increase in blood pressure, and proximal tubule volume } \\
\text { reabsorption } \\
\text { - Decrease in serum angiotensin II level } \\
\text { - No change in glomerular filtration rate }\end{array}$ \\
\hline
\end{tabular}

Experimental Increase in TNF-a production and pro-apoptotic and profibrotic signaling leading to increased apoptotic cell death, tubulointerstitial fibrosis, and renal dysfunction

Experimental - Low doses attenuated castration-associated increases in urine albumin excretion, glomerulosclerosis, and tubulointerstitial fibrosis

- High doses exacerbated castration-associated increases in urine albumin excretion, glomerulosclerosis, and tubulointerstitial fibrosis

Experimental - Increase in blood pressure \& renal sodium reabsorption - Increase in glomerulosclerosis

Experimental Inducing podocyte apoptosis by androgen receptor activation, independent of the TGF- $\beta 1$ signaling pathway

Experimental - Attenuating albuminuria, glomerulosclerosis, and tubulointerstitial fibrosis

- Decrease in the density of renal cortical CD68-positive cells Decrease in the expression of transforming growth factor$\beta$, collagen type IV, TNF- $a$, and IL-6

Case report - Arterial hypertension, oliguria, leukocyturia, hematuria and and case proteinuria, increase in serum urea and creatinine

series - Moderate interstitial inflammatory infiltrate with eosinophils, interstitial edema, calcium deposits, and mild acute tubular necrosis

- Increase in serum urea and creatinine, hematuria and proteinuria

- Mild interstitial lymphmononuclear inflammatory infiltrate with eosinophils without remarkable tubular abnormalities

- Interstitial nephritis and hypercalcemia secondary to vitamin D intoxication caused acute kidney injury

Case series - Proteinuria, renal insufficiency, and nephrotic syndrome - Focal segmental glomerulosclerosis, tubular atrophy, and interstitial fibrosis

Case report - High serum creatinine, high serum urea, low hemoglobin level

- Intrinsic renal parenchymal and focal segmental glomerulosclerosis

Case report Acute kidney injury with the pathology of diffuse acute tubular injury due to bile acid nephropathy with the pathology of tubular bile acid casts

Case report Bile cast nephropathy due to cholestatic jaundice characterized by acute tubular epithelial cell damage along with increased serum creatinine and oliguria jaundice with the pathology of bile inclusions within tubular et al. 2016 cells and interstitial edema
Reference

Quan et al.

2004 [29]

Metcalfeet al 2008 [28]

Xu et al. 2009 [56]

Liu\&Ely 2011 [33]

Doublier et Manigrasso et al. 2012

Daher et al. 2009 [20]

Herlitz et al 2010 [57]

Harrington et al. 2011 [58]

Luciano et al. 2014 [19]
Regarding safety, GH can cause a number of adverse reactions, such as muscle pain, joint stiffness and pain, paresthesia, carpal tunnel syndrome, and headache. These adverse effects may be caused through fluid retention and are generally preventable by decreasing the dose [66]. Since GH can affect calcium absorption in the intestine and increase its excretion, calcium balance may be disturbed [72]. Although some evidence have shown that $\mathrm{GH}$ treatment can elevate plasma insulin concentration leading to increased risk of diabetes type II [73], no evidence of high fasting glucose level and diabetes type II was observed 6 years after discontinuing $\mathrm{GH}$ treatment in children born small for gestational age [74]. According to these data, long-term administration of $\mathrm{GH}$ does not increase the risk of diabetes type 2 and metabolic syndrome [74]. Otitis media, scoliosis, slipped 
femoral capital epiphyses, increased risk of malignancies, and sudden death are other rare and also even unproven complications of GH treatment [75].

\section{Growth hormone safety on renal functions}

The functions of $\mathrm{GH}$ are induced directly or indirectly via synthesis of IGF-I. Since GH receptors, IGF-I, IGF-I receptors, and IGF binding proteins are expressed in the kidney tissue, GH and IGF-I can affect different aspects of this organ, such as its morphology and size, GFR, and minerals' hemostasis [76].

$\mathrm{GH}$ can change the level of serum creatinine by its anabolic effects on muscles [77-79]. Although GH administration can increase GFR by about $10-15 \%$ [80], $\mathrm{GH}$ at the dose of $50 \mathrm{ng} / \mathrm{kg} / \mathrm{min}$ for $2 \mathrm{~h}$ did not affect the GFR in healthy men [81]. Similarly, a double-blind, placebo-controlled study implicated that GH administration at the dose of $0.125 \mathrm{IU} / \mathrm{kg}$ per week subcutaneously for the first 4 weeks and $0.25 \mathrm{IU} / \mathrm{kg}$ per week for a subsequent 5 months did not increase GFR [82]. On the other hand, various studies have demonstrated elevation of GFR and renal plasma flow in patients with acromegaly [83-85].

Studies have demonstrated that GH administration in female rats [86] and dogs [87], as well as non-viral GH transmission in mice [88] resulted in the enlargement of kidneys. In line with these findings, renal parenchyma was modified in transgenic mice models by over-expressing genes coding for GH and IGF-I [89]. Wanke et al. observed that not only the mean glomerular volume, but also the number of endothelial and mesangial cells per glomerule increased in the GH transgenic mouse model of progressive renal disease compared to the control group [90]. Over-expression of IGF-I in transgenic mice caused the expansion of extracellular matrix and glomerulosclerosis [91]. In contrast to animal studies, glomerulosclerosis and renal failure are rare among patients with acromegaly [83, 92].

$\mathrm{GH}$ hypersecretion can increase kidney size by about 6-54\% [76]. Although 7 days of GH treatment [93] or 3 days of IGF-I injection [78] did not affect human kidney size, GH administration for 6 months in individuals with GH deficiency led to an increase in its size [82, 94]. In accordance to the mentioned statement, a case report described that kidney shrinkage by about 10-20 and $20 \%$ occurred 1 and 5 months after hypophysectomy, respectively [95]. Noting that some studies have demonstrated that the kidney weight/body weight ratio is constant and this increase in the size of kidney is associated with body weight gain $[86,96]$.

Regarding glomerulopathy, GH hypersecretion [77] or subcutaneous injections of $\mathrm{GH}$ (with the dose of $2 \mathrm{IU}$ in the morning and 4IU in the evening for one week) [93] and rhIGF-I (with the dose of $60 \mu \mathrm{g} / \mathrm{kg}$, at 800,1400 and
$2000 \mathrm{~h}$ ) [78] did not significantly alter albuminuria (as an index for glomerular permeability) and $\beta_{2}$-microglobin (as an index for proximal tubular involvement). However, microalbuminuria was significantly increased (but not in a pathological pattern) in acromegalic patients $[79,85]$, especially in those with hypertension or diabetes mellitus [97].

Extracellular volume overload, hypertension, electrolyte disorders (such as hyperphosphatemia, hypophosphaturia, hypercalciuria), and urine acidification with reduced kaliuria are other consequences of $\mathrm{GH}$ hypersecretion [76]. Inversely, GH treatment caused extracellular volume reduction in patients with GH deficiency [95, 98]. In addition to extracellular volume overload, $\mathrm{GH}$ can increase sodium and water reabsorption from renal tubules $[85,99]$. It can also activate RAAS $[99,100]$ which may lead to hypertension.

Considering the fact that growth retardation is a common complication of CKD in children, $\mathrm{GH}$ has been used to treat short stature in this population, including children under conservative treatment or hemodialysis and the ones who are kidney transplant recipients [101]. A meta-analysis of 16 relevant studies (including 809 children) published from 1980 to 2011 demonstrated that apart from clinical efficacy, GH therapy did not alter kidney function (e.g., GFR) nor did it increase episodes of acute rejection, compared to placebo in children with CKD (pre-dialysis, dialysis) or transplanted kidney, respectively [102].

Overall, although GH may adversely affect different aspects of kidney such as size, GFR, and tubule functions either directly or indirectly, it has not been clarified yet whether GH at doses used by athletes and body builders can truly cause kidney dysfunction. In addition, there is no definite and conclusive clinical evidence about the detrimental effects of GH on the kidney in these populations. Details of published experimental and clinical studies about the renal safety of $\mathrm{GH}$ in the order of study type (first experimental and after that clinical) and publication year are summarized in the Table 2 .

\section{Conclusion}

More than one-third (38.1\%) of included studies about possible effects of anabolic-androgenic steroids and $\mathrm{GH}$ on the kidney were animal investigations. Experimental findings suggest that GH may adversely affect different aspects of kidney such as size, GFR, and tubule functions, either directly or indirectly. However, clinical data about the potential adverse effects of $\mathrm{GH}$ on the kidney of healthy athletes and bodybuilders is limited. Furthermore, none of the current clinical trials regarding $\mathrm{GH}$ were graded as high quality. In contrast to $\mathrm{GH}$, anabolic-androgenic steroids, such as testosterone, dihydrotestosterone, and nandrolone have caused more 
Table 2 Summary of experimental and clinical studies about the renal safety of growth hormone $(n=9)$

\begin{tabular}{|c|c|c|c|c|}
\hline Dose \& Duration & Subjects & Type of study & Main results & Reference \\
\hline $\begin{array}{l}2.5,5,10 \text {, and } 20 \mathrm{IU} / \mathrm{kg} / \text { day } \\
\text { subcutaneously for } 4-60 \text { days }\end{array}$ & Female rats & Experimental & $\begin{array}{l}\text { - Dose-dependent increase in } \\
\text { renal weight } \\
\text { - No change in kidney dry weight/ } \\
\text { body weight ratio } \\
\text { - Increase in renal glomerular and } \\
\text { tubular cell proliferation and } \\
\text { renal DNA/protein ratio }\end{array}$ & $\begin{array}{l}\text { Mehls et al. } \\
1993 \text { [86] }\end{array}$ \\
\hline $\begin{array}{l}0.025,0.1 \text {, and } 1 \mathrm{IU} / \mathrm{kg} / \text { day } \\
\text { subcutaneously for } 14 \text { weeks }\end{array}$ & Male and female dogs & Experimental & $\begin{array}{l}\text { - Increase in body weight gain } \\
\text { and kidney weights } \\
\text { - Glomerular deposits, mesangial } \\
\text { thickening, and very slight } \\
\text { cellular infiltration in glomeruli } \\
\text { - Increase in the renal glomerular } \\
\text { area } \\
\text { - Glomerular basal lamina } \\
\text { thickening } \\
\text { - Increase in mesangial matrix }\end{array}$ & $\begin{array}{l}\text { Molon- } \\
\text { Noblot et al. } \\
2000[87]\end{array}$ \\
\hline 5-10 mg/day for 3-9 days & $\begin{array}{l}2 \text { patients with hypopituitarism, } 1 \\
\text { with cirrhosis of the liver and } 2 \\
\text { with chronic nephritis and uremia }\end{array}$ & Case report & $\begin{array}{l}\text { - Decrease in plasma urea level } \\
\text { and urea excretion } \\
\text { - Prompt increase in creatinine } \\
\text { clearance and phosphorus } \\
\text { reabsorption }\end{array}$ & $\begin{array}{l}\text { Gershberg } \\
1960[80]\end{array}$ \\
\hline $\begin{array}{l}\text { More than } 400 \mathrm{mg} / \text { week testosterone } \\
\text { proprionate and/or nandrolone } \\
\text { deconate intramuscularly }\end{array}$ & $\begin{array}{l}4 \text { body builders aged between } 20 \\
\text { and } 26 \text { years }\end{array}$ & Case report & $\begin{array}{l}\text { - Increase in serum creatinine and } \\
\text { decreased in eGFR } \\
\text { - Development of acute tubular } \\
\text { necrosis }\end{array}$ & $\begin{array}{l}\text { Almukhtar } \\
\text { et al. } 2015 \\
\text { [22] }\end{array}$ \\
\hline $50 \mathrm{ng} / \mathrm{kg} / \mathrm{min}$ as an infusion for $2 \mathrm{~h}$ & Healthy men & Pilot clinical trial & $\begin{array}{l}\text { - Decrease in renal plasma flow } \\
\text { - No change in GFR }\end{array}$ & $\begin{array}{l}\text { Parving et } \\
\text { al. } 1978 \text { [81] }\end{array}$ \\
\hline $\begin{array}{l}2 \mathrm{IU} \text { in the morning and } 4 \mathrm{IU} \text { in the } \\
\text { evening subcutaneously for } 1 \text { week }\end{array}$ & Healthy men & Pilot clinical trial & $\begin{array}{l}\text { - Increase in GFR and renal plasma } \\
\text { flow } \\
\text { - No significant change in kidney } \\
\text { size and urinary excretion rates } \\
\text { of albumin and } \beta 2 \text {-microglobulin }\end{array}$ & $\begin{array}{l}\text { Christiansen } \\
\text { et al. } 1981 \\
\text { [93] }\end{array}$ \\
\hline $\begin{array}{l}0.125 \mathrm{IU} / \mathrm{kg} \text { per week subcutaneously } \\
\text { for the first } 4 \text { weeks and } 0.25 \mathrm{IU} / \mathrm{kg} \text { per } \\
\text { week for the subsequent } 5 \text { months }\end{array}$ & Growth hormone deficient adults & $\begin{array}{l}\text { Double-blind, } \\
\text { placebo-controlled, } \\
\text { cross-over clinical } \\
\text { trial }\end{array}$ & $\begin{array}{l}\text { - No change in GFR and renal } \\
\text { plasma flow } \\
\text { - No effect on kidney size }\end{array}$ & $\begin{array}{l}\text { Riedl et al. } \\
1995 \text { [82] }\end{array}$ \\
\hline $\begin{array}{l}0.02 \mathrm{IU} / \mathrm{kg} / \text { day (or } 7 \mu \mathrm{g} / \mathrm{kg} / \mathrm{day} \text { ) } \\
\text { subcutaneously for } 10 \text { months }\end{array}$ & $\begin{array}{l}\text { Adults with childhood onset GH } \\
\text { deficiency }\end{array}$ & Pilot clinical trial & $\begin{array}{l}\text { - Increase in left ventricular-mass } \\
\text { index and kidney length } \\
\text { - No abnormalities or change in } \\
\text { the urine analysis }\end{array}$ & $\begin{array}{l}\text { Link et al. } \\
2001[94]\end{array}$ \\
\hline $\begin{array}{l}6 \mathrm{IU} / \mathrm{m}^{2} \text { per day subcutaneously for } 6 \\
\text { days }\end{array}$ & Healthy volunteer males & $\begin{array}{l}\text { Randomized, cross- } \\
\text { over clinical trial }\end{array}$ & $\begin{array}{l}\text { - Increase in the plasma renin } \\
\text { - Increase in distal tubule sodium } \\
\text { and water reabsorption } \\
\text { - Decrease in mean 24-h urinary } \\
\text { output and mean 24-h urinary } \\
\text { sodium excretion }\end{array}$ & $\begin{array}{l}\text { Hansen et } \\
\text { al. } 2001 \text { [99] }\end{array}$ \\
\hline
\end{tabular}

prominent renal disorders ranged from a mild, reversible rise in serum creatinine and blood urine nitrogen to irreversible CKD and FSGS leading to renal replacement therapy through a number of mechanisms. They include potentiating RAAS, enhancing the production of endothelin, producing reactive oxygen species, promoting oxidative stress, inducing apoptosis and inflammatory cytokines (such as TNF- $\alpha$, IL-1b, and IL-6), and over-expression of pro-fibrotic and pro-apoptotic mediators, such as TGF- $\beta 1$. However, it should be noted that kidney involvement in athletes receiving anabolic-androgenic steroids can be at least partially attributed to other independent factors and mechanisms such as high-protein diet (via increase in renal blood flow and GFR), elevated blood pressure (via hypertensive arterionephrosclerosis), bile acid nephropathy (secondary to cholestatic jaundice), rhabdomyolysis, and nephrocalcinosis (secondary to exogenous vitamin D intoxication). In addition, at least one large cohort study conducted by the National Football League on 1063 retired professional football players in the US who may have taken supplements such as anabolic-androgenic steroids and 
$\mathrm{GH}$, demonstrated that the rate of renal problems in these individuals were comparable with the general population [103]. Therefore, the above findings about anabolic-androgenic steroid adverse effects on the kidney and their relevant mechanisms reported from experimental studies along with case report as well as case series should be reproduced in at least cohort clinical studies with long-term follow-up before any definite interpretation, recommendation, and practice in this regards. The Russian athletes from the Former Soviet Union and also Iranian ones, especially the weightlifters can be suitable populations for these studies. Unfortunately, there is no published data from these populations to the best of knowledge. Finally, the defined daily dose and duration of GH and anabolic-androgenic steroids that can be used by athletes and bodybuilders with minimal concerns regarding their renal safety are other questions that should be taken into account in future clinical investigations.

\section{Abbreviations}

AKI: Acute kidney injury; CKD: Chronic kidney disease; ESRD: End stage renal disease; FSGS: Focal segmental glomerulosclerosis; GH: Growth hormone; IGF: Insulin-like growth factor; IGFBP: Insulin-like growth factor binding protein; IL: Interleukin; RAAS: Renin-angiotensin-aldosterone system; TNF: Tumor necrosis facto

\section{Acknowledgements}

The authors would like to appreciate Professor Mohammad Mahdi Sagheb for proposing this topic and designing the general format of this systematic review. We would also grateful for Dr. Dena Firouzabadi and Dr. Mahtabalsadat Mirjalili for their valuable and critical English editing of the manuscript.

\section{Funding}

No funding support

\section{Availability of data and materials}

$$
\text { Not applicable. }
$$

\section{Authors' contributions}

DDD and IK searched the literature, extracted the relevant articles, and drafted the manuscript. HK evaluated the quality of recruited clinical studies, interpreted the study results, and critically edited the manuscript. All authors read and approved the final version of the manuscript before submission.

\section{Ethics approval and consent to participate}

Not applicable.

\section{Consent for publication}

Not applicable.

\section{Competing interests}

The authors declare that they have no competing interests.

\section{Publisher's Note}

Springer Nature remains neutral with regard to jurisdictional claims in published maps and institutional affiliations.

\section{Author details}

'Department of Clinical Pharmacy, Faculty of Pharmacy, Shiraz University of Medical Sciences, Karafarin street, P O Box: 7146864685, Shiraz, Iran. ${ }^{2}$ Department of Clinical Pharmacy, Faculty of Pharmacy, Tehran University of Medical Sciences, Tehran, Iran.
Received: 4 January 2019 Accepted: 15 May 2019

Published online: 31 May 2019

\section{References}

1. Maughan RJ, editor. Sports nutrition. Oxford: Wiley-Blackwell; 2014.

2. Ehrnborg C, Rosén T. The psychology behind doping in sport. Growth Hormon IGF Res. 2009:19:285-7.

3. Supplement Business Report 2016. New York, NY: Penton Nutrition Business Journal 2017.

4. Lieberman HR, Marriott BP, Williams C, Judelson DA, Glickman EL, Geiselman PJ, Dotson L, Mahoney CR. Patterns of dietary supplement use among college students. Clin Nutr. 2015;34:976-85.

5. Rexroat R. NCAA national study of substance use habits of college studentathletes. Natl Coll Athl Assoc. 2014:1-101.

6. Perry PJ, Lund BC, Deninger MJ, Kutscher EC, Schneider J. Anabolic steroid use in weightlifters and bodybuilders: an internet survey of drug utilization. Clin J Sport Med. 2005;15:326-30.

7. Daher EDF, Martiniano LVM, Lima LLL, Leite Filho NCV, de Oliveira Souza LE, Fernandes PHPD, da Silva SL, da Silva Junior GB. Acute kidney injury due to excessive and prolonged intramuscular injection of veterinary supplements containing vitamins a, D and E: a series of 16 cases. nefrologia. 2017;37:61-7.

8. Timcheh-Hariri A, Balali-Mood M, Aryan E, Sadeghi M, Riahi-Zanjani B. Toxic hepatitis in a group of 20 male body-builders taking dietary supplements. Food Chem Toxicol. 2012;50:3826-32.

9. Liberati A, Altman DG, Tetzlaff J, Mulrow C, Gøtzsche PC, loannidis JP, Clarke M, Devereaux PJ, Kleijnen J, Moher D. The PRISMA statement for reporting systematic reviews and meta-analyses of studies that evaluate health care interventions: explanation and elaboration. PLoS Med. 2009;6:e1000100.

10. Fortunato RS, Rosenthal D, DPd C. Abuse of anabolic steroids and its impact on thyroid function. Arq Bras Endocrinol Metabol. 2007;51:1417-24.

11. Sjöqvist F, Garle M, Rane A. Use of doping agents, particularly anabolic steroids, in sports and society. Lancet. 2008;371:1872-82.

12. Iriart JAB, TMd A. Body-building, steroid use, and risk perception among young body-builders from a low-income neighborhood in the city of Salvador, Bahia state, Brazil. Cad Saude Publica. 2002:18:1379-87.

13. Kanayama G, Pope HG. History and epidemiology of anabolic androgens in athletes and non-athletes. Mol Cell Endocrinol. 2017.

14. Santos AF, Mendonça PMH, Santos LA, Silva NF, Tavares JKL. Anabolic steroids: concepts according to muscular activity practisers in Aracaju (SE). Psicologia em Estudo. 2006;11:371-80.

15. Johnson CA. Use of androgens in patients with renal failure. In: Seminars in dialysis: Wiley Online Library; 2000. p. 36-9.

16. Chapter 3: Use of ESAs and other agents to treat anemia in CKD. Kidney Int Suppl (2011). 2012;2:299-310

17. Bird SR, Goebel C, Burke LM, Greaves RF. Doping in sport and exercise: anabolic, ergogenic, health and clinical issues. Ann Clin Biochem. 2016;53:196-221.

18. Goldman A, Basaria S. Adverse health effects of androgen use. Mol Cell Endocrinol. 2017.

19. Luciano RL, Castano E, Moeckel G, Perazella MA. Bile acid nephropathy in a bodybuilder abusing an anabolic androgenic steroid. Am J Kidney Dis. 2014; 64:473-6.

20. Daher EF, Júnior GBS, Queiroz AL, Ramos LM, Santos SQ, Barreto DM, Guimarães AAC, Barbosa CA, Franco LM, Patrocínio RM. Acute kidney injury due to anabolic steroid and vitamin supplement abuse: report of two cases and a literature review. Int Urol Nephrol. 2009;41:717-23.

21. Libório AB, Nasserala JC, Gondim AS, Daher EF. The case| renal failure in a bodybuilder athlete. Kidney Int. 2014;85:1247-8.

22. Almukhtar SE, Abbas AA, Muhealdeen DN, Hughson MD. Acute kidney injury associated with androgenic steroids and nutritional supplements in bodybuilders. Clin Kidney J. 2015;8:415-9.

23. Tabatabaee SM, Elahi R, Savaj S. Bile cast nephropathy due to cholestatic jaundice after using stanozolol in 2 amateur bodybuilders. Iran J Kidney Dis. 2015:9.

24. Alkhunaizi AM, ElTigani MA, Rabah RS, Nasr SH. Acute bile nephropathy secondary to anabolic steroids. Clin Nephrol. 2016:85:121-6.

25. Tsuji S, Sugiura M, Tsutsumi S, Yamada H. Sex differences in the excretion levels of traditional and novel urinary biomarkers of nephrotoxicity in rats. J Toxicol Sci. 2017;42:615-27.

26. Schaefer F, Mehls $\mathrm{O}$, Ritz E. New insights into endocrine disturbances of chronic renal failure. Miner Electrolyte Metab. 1991;18:169-73. 
27. Dousdampanis P, Trigka K, Fourtounas C, Bargman JM. Role of testosterone in the pathogenesis, progression, prognosis and comorbidity of men with chronic kidney disease. Ther Apher Dial. 2014;18:220-30.

28. Metcalfe PD, Leslie JA, Campbell MT, Meldrum DR, Hile KL, Meldrum KK Testosterone exacerbates obstructive renal injury by stimulating TNF-a production and increasing proapoptotic and profibrotic signaling. Am J Physiol Endocrinol Metab. 2008;294:E435-43.

29. Quan A, Chakravarty S, Chen J-K, Chen J-C, Loleh S, Saini N, Harris RC, Capdevila J, Quigley R. Androgens augment proximal tubule transport. Am J Physiol Ren Physiol. 2004;287:F452-9.

30. Alexander BT, Cockrell KL, Rinewalt AN, Herrington JN, Granger JP. Enhanced renal expression of preproendothelin mRNA during chronic angiotensin II hypertension. Am J Phys Regul Integr Comp Phys. 2001;280: R1388-92.

31. Song J, Eyster KM, Kost CK, Kjellsen B, Martin DS. Involvement of protein kinase C-CPI-17 in androgen modulation of angiotensin II-renal vasoconstriction. Cardiovasc Res. 2010;85:614-21.

32. Mukai Y, Shimokawa H, Matoba T, Kandabashi T, Satoh S, Hiroki J, Kaibuchi K, Takeshita A. Involvement of rho-kinase in hypertensive vascular disease: a novel therapeutic target in hypertension. FASEB J. 2001;15:1062-4.

33. Liu B, Ely D. Testosterone increases: sodium reabsorption, blood pressure, and renal pathology in female spontaneously hypertensive rats on a high sodium diet. Adv Pharmacol Sci. 2011;2011.

34. Loh SY, Giribabu N, Gholami K, Salleh N. Effects of testosterone on mean arterial pressure and aquaporin (AQP)-1, 2, 3, 4, 6 and 7 expressions in the kidney of orchidectomized, adult male Sprague-Dawley rats. Arch Biochem Biophys. 2017;614:41-9.

35. Svartberg J. Epidemiology: testosterone and the metabolic syndrome. Int J Impot Res. 2007;19:124-8.

36. Svartberg J, von Muhlen D, Schirmer H, Barrett-Connor E, Sundfjord J, Jorde R. Association of endogenous testosterone with blood pressure and left ventricular mass in men. The Tromso study. Eur J Endocrinol. 2004;150:65-71.

37. Zitzmann M, Nieschlag E. Androgen receptor gene CAG repeat length and body mass index modulate the safety of long-term intramuscular testosterone undecanoate therapy in hypogonadal men. J Clin Endocrinol Metab. 2007:92:3844-53.

38. Kalk P, Thöne-Reineke C, Schwarz A, Godes M, Bauer C, Pfab T, Hocher B. Renal phenotype of ET-1 transgenic mice is modulated by androgens. Eur J Med Res. 2009;14:55.

39. Guan Z, VanBeusecum JP, Inscho EW. Endothelin and the renal microcirculation. Semin Nephrol. 2015;35:145-55.

40. Agarwal R. Chronic kidney disease is associated with oxidative stress independent of hypertension. Clin Nephrol. 2004;61:377-83.

41. Cho MH, Jung K-J, Jang H-S, Kim Jl, Park KM. Orchiectomy attenuates kidney fibrosis after ureteral obstruction by reduction of oxidative stress in mice. Am J Nephrol. 2011;35:7-16.

42. Verzola D, Villaggio B, Procopio V, Gandolfo MT, Gianiorio F, Famà A, Tosetti F, Traverso P, Deferrari G, Garibotto G. Androgen-mediated apoptosis of kidney tubule cells: role of c-Jun amino terminal kinase. Biochem Biophys Res Commun. 2009;387:531-6.

43. D'agostino P, Milano S, Barbera C, Bella G, Rosa M, Ferlazzo V, Farruggio R, Miceli D, Miele M, Castagnetta L. Sex Hormones Modulate Inflammatory Mediators Produced by Macrophagesa. Ann N Y Acad Sci. 1999;876:426-9.

44. Li Z, Danis V, Brooks P. Effect of gonadal steroids on the production of IL-1 and IL-6 by blood mononuclear cells in vitro. Clin Exp Rheumatol. 1992;11: 157-62.

45. Gornstein RA, Lapp CA, Bustos-Valdes SM, Zamorano P. Androgens modulate interleukin-6 production by gingival fibroblasts in vitro. J Periodontol. 1999;70:604-9.

46. Culig Z. Androgen receptor cross-talk with cell signalling pathways. Growth Factors. 2004;22:179-84.

47. Delfino FJ, Boustead JN, Fix C, Walker WH. NF-kB and TNF-a stimulate androgen receptor expression in Sertoli cells. Mol Cell Endocrinol. 2003;201:1-12.

48. Doublier S, Lupia E, Catanuto P, Periera-Simon S, Xia X, Korach K, Berho M, Elliot SJ, Karl M. Testosterone and 17ß-estradiol have opposite effects on podocyte apoptosis that precedes glomerulosclerosis in female estrogen receptor knockout mice. Kidney Int. 2011;79:404-13.

49. Hall YN, Fuentes EF, Chertow GM, Olson JL. Race/ethnicity and disease severity in IgA nephropathy. BMC Nephrol. 2004;5:10.

50. Terada N, Arai Y, Kinukawa N, Yoshimura K, Terai A. Risk factors for rena cysts. BJU Int. 2004;93:1300-2.
51. Donadio JV, Torres VE, Velosa JA, Wagoner RD, Holley KE, Okamura M, IIstrup DM, Chu C-P. Idiopathic membranous nephropathy: the natural history of untreated patients. Kidney Int. 1988;33:708-15.

52. Mangili R, Deferrari G, Di Mario U, Giampietro O, Navalesi R, Nosadini R, Rigamonti G, Spezia R, Crepaldi G, Group IMS. Arterial hypertension and microalbuminuria in IDDM: the Italian microalbuminuria study. Diabetologia. 1994;37:1015-24.

53. Maric C, Forsblom C, Thorn L, Wadén J, Groop P-H, Group FS. Association between testosterone, estradiol and sex hormone binding globulin levels in men with type 1 diabetes with nephropathy. Steroids. 2010;75:772-8.

54. Manigrasso MB, Sawyer RT, Marbury DC, Flynn ER, Maric C. Inhibition of estradiol synthesis attenuates renal injury in male streptozotocin-induced diabetic rats. Am J Physiol Ren Physiol. 2011;301:F634-40.

55. Manigrasso MB, Sawyer RT, Hutchens ZM, Flynn ER, Maric-Bilkan C. Combined inhibition of aromatase activity and dihydrotestosterone supplementation attenuates renal injury in male streptozotocin (STZ)induced diabetic rats. Am J Physiol Ren Physiol. 2012;302:F1203-9.

56. Xu Q, Prabhu A, Xu S, Manigrasso MB, Maric C. Dose-dependent effects of dihydrotestosterone in the streptozotocin-induced diabetic rat kidney. Am J Physiol Ren Physiol. 2009;297:F307-15.

57. Herlitz LC, Markowitz GS, Farris AB, Schwimmer JA, Stokes MB, Kunis C, Colvin RB, D'Agati VD. Development of focal segmental glomerulosclerosis after anabolic steroid abuse. J Am Soc Nephrol. 2010;21:163-72.

58. Harrington P, Ali G, Chan A. The development of focal segmental glomerulosclerosis secondary to anabolic steroid abuse. BMJ Case Rep. 2011;2011:bcr0720114531.

59. Turillazzi E, Perilli G, Di Paolo M, Neri M, Riezzo I, Fineschi V. Side effects of AAS abuse: an overview. Mini Rev Med Chem. 2011;11:374-89.

60. Drake WM, Howell SJ, Monson J, Shalet SM. Optimizing GH therapy in adults and children. Endocr Rev. 2001:22:425-50.

61. Bunderen CC, Varsseveld NC, Erfurth EM, Ket JC, Drent ML. Efficacy and safety of growth hormone treatment in adults with growth hormone deficiency: a systematic review of studies on morbidity. Clin Endocrinol. 2014;81:1-14.

62. Butler G. Indications for growth hormone therapy. Paediatr Child Health. 2007;17:356-60.

63. Giustina A, Veldhuis JD. Pathophysiology of the neuroregulation of growth hormone secretion in experimental animals and the human. Endocr Rev. 1998;19:717-97.

64. Chen EY, Liao Y-C, Smith DH, Barrera-Saldaña HA, Gelinas RE, Seeburg PH. The human growth hormone locus: nucleotide sequence, biology, and evolution. Genomics. 1989;4:479-97.

65. Baumann GP. Growth hormone doping in sports: a critical review of use and detection strategies. Endocr Rev. 2012;33:155-86.

66. Höybye C, Christiansen JS. Growth hormone replacement in adults-current standards and new perspectives. Best Pract Res Clin Endocrinol Metab. 2015:29:115-23.

67. Yarasheski KE, Campbell JA, Smith K, Rennie M, Holloszy J, Bier D. Effect of growth hormone and resistance exercise on muscle growth in young men. Am J Physiol. 1992;262:E261-7.

68. Yarasheski KE, Zachweija J, Angelopoulos TJ, Bier DM. Short-term growth hormone treatment does not increase muscle protein synthesis in experienced weight lifters. J Appl Physiol. 1993;74:3073-6.

69. Liu H, Bravata DM, Olkin I, Friedlander A, Liu V, Roberts B, Bendavid E, Saynina O, Salpeter SR, Garber AM. Systematic review: the effects of growth hormone on athletic performance. Ann Intern Med. 2008;148:747-58.

70. Meinhardt U, Nelson AE, Hansen JL, Birzniece V, Clifford D, Leung K-C, Graham K, Ho KK. The effects of growth hormone on body composition and physical performance in recreational athletes. Ann Intern Med. 2010; 152:568-79.

71. Sharp R. Land of the giants. Growth Hormon IGF Res. 2009;19:291-3.

72. Pawlikowska-Haddal A. Growth hormone therapy with norditropin (somatropin) in growth hormone deficiency. Expert Opin Biol Ther. 2013;13: 927-32.

73. Cutfield WS, Wilton P, Bennmarker H, Albertsson-Wikland K, Chatelain P, Ranke MB, Price DA. Incidence of diabetes mellitus and impaired glucose tolerance in children and adolescents receiving growth-hormone treatment. Lancet. 2000;355:610-3.

74. van Dijk M, Bannink EM, van Pareren YK, Mulder PG, Hokken-Koelega AC. Risk factors for diabetes mellitus type 2 and metabolic syndrome are comparable for previously growth hormone-treated young adults born 
small for gestational age (SGA) and untreated short SGA controls. J Clin Endocrinol Metabol. 2007;92:160-5.

75. Carel J-C, Butler G. Safety of recombinant human growth hormone. In: Hindmarsh PC, editor. Current indications for growth hormone therapy. Basel: Karger; 2010. p. 40-54.

76. Grunenwald S, Tack I, Chauveau D, Bennet A, Caron P. Impact of growth hormone hypersecretion on the adult human kidney. Ann Endocrinol (Paris). 2011;72:485-95.

77. Eskildsen P, Parving HH, Mogensen C, Christiansen JS. Kidney function in acromegaly. J Intern Med. 1979;205:79-82.

78. Hirschberg R, Brunori G, Kopple JD, Guler H-P. Effects of insulin-like growth factor I on renal function in normal men. Kidney Int. 1993;43:387-97.

79. Hoogenberg K, Sluiter WI, Dullaart RP. Effect of growth hormone and insulinlike growth factor I on urinary albumin excretion: studies in acromegaly and growth hormone deficiency. Acta Endocrinol. 1993;129:151-7.

80. Gershberg H. Metabolic and renotropic effects of human growth hormone in-disease. J Clin Endocrinol Metab. 1960;20:1107-19.

81. Parving $\mathrm{H}-\mathrm{H}$, Noer I, Mogensen C, Svendsen PA. Kidney function in normal man during short-term growth hormone infusion. Acta Endocrinol. 1978;89: 796-800.

82. Riedl M, Hass M, Oberbauer R, Gisinger J, Luger A, Mayer G. The effects of prolonged substitution of recombinant human growth hormone on renal functional reserve in growth hormone-deficient adults. J Am Soc Nephrol. 1995;6:1434-8.

83. Gershberg $\mathrm{H}$, Heinemann $\mathrm{H}$, Stumpf $\mathrm{H}$. Renal function studies and autopsy report in a patient with gigantism and acromegaly. J Clin Endocrinol Metab. 1957:17:377-85.

84. Falkheden T, Sjögren B. Extracellular fluid volume and renal function in pituitary insufficiency and acromegaly. Acta Endocrinol. 1964;46:80-8.

85. Auriemma RS, Galdiero M, De Martino MC, De Leo M, Grasso LF, Vitale P, Cozzolino A, Lombardi G, Colao A, Pivonello R. The kidney in acromegaly: renal structure and function in patients with acromegaly during active disease and 1 year after disease remission. Eur J Endocrinol. 2010;162:1035-42.

86. Mehls O, Irzynjec T, Ritz E, Eden S, Kovàcs G, Klaus G, Floege J, Mall G. Effects of rhGH and rhlGF-1 on renal growth and morphology. Kidney Int. 1993:44:1251-8

87. Molon-Noblot $S$, Laroque $P$, Prahalada $S$, Stabinski LG, Peter CP, Duprat $P$, Van Zwieten MJ. Morphological changes in the kidney of dogs chronically exposed to exogenous growth hormone. Toxicol Pathol. 2000;28:510-7.

88. Khamaisi M, Søndergaard M, Segev Y, Dagnaes-Hansen F, Jensen TG, Landau D, Raz I, Flyvbjerg A. Differential effects on kidney and liver growth of a non-viral hGH-expression vector in hypophysectomized mice. Growth Hormon IGF Res. 2007;17:279-87.

89. Doi T, Striker LJ, Quaife C, Conti FG, Palmiter R, Behringer R, Brinster R, Striker G. Progressive glomerulosclerosis develops in transgenic mice chronically expressing growth hormone and growth hormone releasing factor but not in those expressing insulinlike growth factor-1. Am J Pathol. 1988;131:398.

90. Wanke R, Wolf E, Brem G, Hermanns W. Role of podocyte damage in the pathogenesis of glomerulosclerosis and tubulointerstitial lesions: findings in the growth hormone transgenic mouse model of progressive nephropathy. Verh Dtsch Ges Pathol. 2001;85:250-6.

91. Doublier S, Seurin D, Fouqueray B, Verpont M-C, Callard P, Striker L, Strike GE, Binoux M, Baud L. Glomerulosclerosis in mice transgenic for human insulin-like growth factor-binding protein-1. Kidney Int. 2000:57:2299-307.

92. Newbold K, Howie A, Girling A, Kizaki T, Bryan R, Carey M. A simple method for assessment of glomerular size and its use in the study of kidneys in acromegaly and compensatory renal enlargement. J Pathol. 1989;158:139-46.

93. Christiansen JS, Gammelgaard J, Ørskov H, Andersen A, Telmer S, PARVING $\mathrm{HH}$. Kidney function and size in normal subjects before and during growth hormone administration for one week. Eur J Clin Investig. 1981;11:487-90.

94. Link K, Bülow B, Westman K, Salmonsson EC, Eskilsson J, Erfurth EM. Low individualized growth hormone $(\mathrm{GH})$ dose increased renal and cardiac growth in young adults with childhood onset GH deficiency. Clin Endocrinol. 2001;55:741-8.

95. Falkheden T, Wickbom I. Renal function and kidney size following hypophysectomy in man. Acta Endocrinol. 1965;48:348-54.

96. Doi T, Striker LJ, Gibson CC, Agodoa L, Brinster RL, Striker GE. Glomerular lesions in mice transgenic for growth hormone and insulinlike growth factor-II relationship between increased glomerular size and mesangia sclerosis. Am J Pathol. 1990;137:541.
97. Baldelli R, De Marinis L, Bianchi A, Pivonello R, Gasco V, Auriemma R, Pasimeni G, Cimino V, Appetecchia M, Maccario M. Microalbuminuria in insulin sensitivity in patients with growth hormone-secreting pituitary tumor. J Clin Endocrinol Metab. 2008:93:710-4.

98. Johannsson G, Sverrisdóttir YB, Ellegård L, Lundberg P-A, Herlitz H. GH increases extracellular volume by stimulating sodium reabsorption in the distal nephron and preventing pressure natriuresis. J Clin Endocrinol Metab. 2002;87:1743-9.

99. Hansen TK, Møller J, Thomsen K, Frandsen E, Dall R, Jørgensen JO, Christiansen JS. Effects of growth hormone on renal tubular handling of sodium in healthy humans. Am J Physiol Endocrinol Metab. 2001;281: E1326-32.

100. Dimke H, Flyvbjerg A, Frische S. Acute and chronic effects of growth hormone on renal regulation of electrolyte and water homeostasis. Growth Hormon IGF Res. 2007:17:353-68.

101. Bérard E, André JL, Guest G, Berthier F, Afanetti M, Cochat P, Broyer M. Long-term results of $\mathrm{rhGH}$ treatment in children with renal failure: experience of the French Society of Pediatric Nephrology. Pediatr Nephrol. 2008:23:2031.

102. Hodson EM, Willis NS, Craig JC. Growth hormone for children with chronic kidney disease. Cochrane Libr. 2012.

103. Weir DR, Jackson JS, Sonnega A. National football leaque player care foundation study of retired NFL players. Ann Arbor: University of Michigan Institute for Social Research; 2009.

\section{Ready to submit your research? Choose BMC and benefit from:}

- fast, convenient online submission

- thorough peer review by experienced researchers in your field

- rapid publication on acceptance

- support for research data, including large and complex data types

- gold Open Access which fosters wider collaboration and increased citations

- maximum visibility for your research: over $100 \mathrm{M}$ website views per year

At BMC, research is always in progress.

Learn more biomedcentral.com/submissions 